\title{
Severe ulcerative oesophagitis caused by primary Epstein-Barr virus infection in an immunocompetent individual
}

\author{
Ruben Due Lorentsen, ${ }^{1}$ Louise Laurberg Klarskov, ${ }^{2}$ Casper Steenholdt (D) ${ }^{1}$
}

To cite: Lorentsen RD, Klarskov LL, Steenholdt C. Severe ulcerative oesophagitis caused by primary EpsteinBarr virus infection in an immunocompetent individual. BMJ Open Gastro 2021;8:e000586. doi:10.1136/ bmjgast-2020-000586

Received 2 December 2020 Revised 12 January 2021 Accepted 13 January 2021
Check for updates

(C) Author(s) (or their employer(s)) 2021. Re-use permitted under CC BY-NC. No commercial re-use. See rights and permissions. Published by BMJ.

${ }^{1}$ Department of

Gastroenterology, Herlev and Gentofte Hospital, Herlev, Denmark

${ }^{2}$ Department of Pathology, Herlev and Gentofte Hospital, Herlev, Denmark

Correspondence to Dr Casper Steenholdt; steenholdt@dadlnet.dk

\section{ABSTRACT}

Epstein-Barr virus (EBV) infects the vast majority of the human population. The primary infection in immunocompetent individuals is typically asymptomatic or presenting as infectious mononucleosis. Here, an 18-year-old man without medical history was admitted with mild non-specific symptoms of infection presenting primarily with severe dysphagia and epigastric pain. Gastroscopy revealed severe, extensive, ulcerative oesophagitis with suspicion of Crohn's disease. However, a diagnosis of primary EBV infection presenting as severe ulcerative oesophagitis and without systemic symptoms of infectious mononucleosis was made based on dynamic changes in EBV serology (shift from IgM to IgG positivity), EBV-specific immunohistochemical staining, and PCR analysis of biopsy specimens. This rare manifestation of primary EBV in an immunocompetent patient was treated symptomatically and resolved within a few weeks, and should be considered a differential diagnosis at otherwise unexplained ulcerative oesophagitis in younger individuals.

\section{INTRODUCTION}

Epstein-Barr virus (EBV) infects $>90 \%$ of the human population worldwide and with a variety of manifestations, notably infectious mononucleosis characterised by fever, lymphadenopathy, pharyngitis, hepatomegaly, and/or splenomegaly. ${ }^{1}$ After the primary infection, EBV is present lifelong as latent infection in B lymphocytes, but reactivation is rare-and if so typically due to immune impairment. ${ }^{1}$ Reactivation of EBV is a known, but rare, cause of infectious oesophagitis in immunosuppressed patients. $^{23}$ In immunocompetent patients, however, primary EBV oesophagitis has only anecdotally been described.

\section{CLINICAL CASE DESCRIPTION}

An 18-year-old male patient with no medical history or sexual risk behaviour, non-smoker and not drinking alcohol was admitted to our hospital due to fever up to $39.4^{\circ} \mathrm{C}$, muscle pain, heartburn, epigastric pain, dysphagia, and odynophagia. The fever had appeared
4 days prior to admission, while the upper gastrointestinal symptoms started on the day before admission. The clinical examination revealed a fit and slender young man, temperature $37.6^{\circ} \mathrm{C}$, pulse 100 , blood pressure $106 / 77 \mathrm{~mm} \mathrm{Hg}$, and with worsening of epigastric tenderness and heartburn at palpation of the epigastrium. The examination was otherwise normal and with no signs of pharyngitis, lymphadenopathy, hepatomegaly, or splenomegaly. Laboratory testings revealed normal complete blood counts including normal leucocytes and neutrophils, increased C-reactive protein of $49 \mathrm{mg} / \mathrm{L}$, and normal liver biochemistry apart from a slightly increased international normalised ratio (INR) of 1.4.

Gastroscopy performed on the following day revealed multiple, centimetre-long, linear and circular ulcerations of various depth of the entire length of the oesophagus (figure 1a). The stomach and duodenum had normal endoscopic appearances. Biopsies from the oesophageal mucosa presented with fragments of well-differentiated squamous epithelium with only few intraepithelial inflammatory cells and the biopsies were dominated by deep ulcerations (figure 1b). Granulomas were not present. There were no morphological signs indicating viral infection, and fungal stainings were negative. The conclusion was unspecific ulcerations. Routine biopsies from the stomach and duodenum were normal. Symptomatic therapy with proton-pump inhibitor (pantoprazole) and mild analgesics (acetaminophen) was initiated. This was followed by rapid symptom improvement and the patient was discharged for further diagnostic workup in the outpatient clinic.

At follow-up 2 weeks after discharge, the patient was feeling well and with normal routine laboratory tests including normalisation of INR. He described that the symptoms of heartburn and epigastric pain had rapidly 

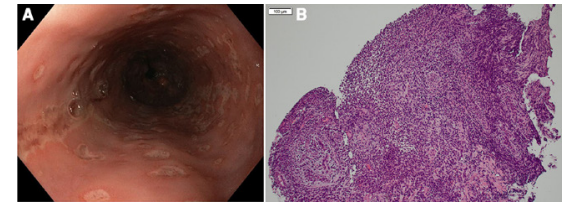

Figure 1 Endoscopic image of the oesophagus revealing multiple, linear and circular, centimetre-long ulcerations of varying depths involving the entire length of the oesophagus (A). Representative biopsy (H\&E) from the oesophageal mucosa (B) presenting with ulcerated surface and granulation tissue, but without granulomas or morphological signs of fungi or viral infection. Immunohistochemical staining for Epstein-Barr virus (EBV) (C) revealing several positive cells (brown) and with subsequent PCR analysis confirming presence of EBV with a quantitative detection of 13 virus particles $/ \mu \mathrm{L}$.

subsided following discharge with a total symptom duration of 8 days after which he had stopped taking any medicine. Due to a faecal calprotectin level of 285 $\mu \mathrm{g} / \mathrm{g}$, MRI was carried out to rule out Crohn's disease, and revealing normal appearance of the small and large bowel. The patient declined repeat gastroscopy or colonoscopy because he was feeling well. Virus serology detected borderline-positive EBV viral capsid antibodies (VCA) IgM, positive EBV VCA IgG, and positive nuclear antibodies (EBV nuclear antigen; EBNA) IgG. Cytomegalovirus (CMV) and varicella-zoster virus were IgG positive and IgM negative, and testings for herpes simplex virus (HSV) and HIV were negative. Thus, serological testings raised suspicion of primary infection with EBV as underlying cause. The biopsies were re-evaluated and found to be positive for EBV by specific EBV immunohistochemical staining (figure 1c). PCR confirmed infection with EBV with a quantitative detection of 13 virus particles/ $\mu \mathrm{L}$. Immunohistochemical stainings for CMV and HSV were negative.

Repeat serology 5 months after discharge showed similar results including borderline-positive EBV VCA IgM and positive EBV VCA IgG and EBNA IgG. However, complete seroconversion had occurred at retesting 9 months after presentation with negative EBV VCA IgM and positive EBV VCA IgG and EBNA IgG, thus confirming that the underlying cause of severe ulcerative oesophagitis had been primary EBV infection.

\section{DISCUSSION}

We report an extremely rare case of EBV oesophagitis caused by primary EBV infection in an otherwise healthy 18-year-old man presenting with mild, nonspecific systemic symptoms of infection, but primarily with severe dysphagia, heartburn, and epigastric pain. EBV oesophagitis rarely occurs due to reactivation in immunocompromised patients, but has only anecdotally been observed as manifestation of the primary infection among immunocompetent individuals (table 1$).{ }^{4-6}$ The three previously reported cases all presented with non-specific symptoms of severe oesophagitis; non-specific, relatively long and deep, circular and linear ulcerations at endoscopy; and without specific histological findings by use of standard stainings. Thus, EBV oesophagitis can neither be detected by clinical presentation, endoscopic appearance, nor by routine evaluation of biopsies. Here, we unambiguously established the diagnosis due to typical dynamic changes in EBV serology, positive EBV-specific immunohistochemical staining, and by use of PCR analysis of biopsy specimens. Of note, two previous cases found false-negative serology and histology, with diagnosis based only on PCR; and another based the diagnosis solely on a positive Monospot test (table 1). ${ }^{56}$

Notable differential diagnoses include infectious oesophagitis caused by other pathogens such as CMV or HSV, gastro-oesophageal reflux disease (GORD), and Crohn's disease. We ruled out other potential infectious pathogens by serology and immunohistochemical stainings. GORD was considered unlikely due to the clinical presentation including rapid symptom evolvement with signs of systemic infection along with endoscopic findings not being classic for GORD. Crohn's disease presenting with inflammatory activity confined only to the oesophagus and without any other gastrointestinal symptoms is rare. ${ }^{7}$ Endoscopic findings of Crohn's disease are heterogeneous and include oedema and reddening, aphtas, ulcers, cobblestone appearance, stenosis, and potentially fistulas. Typical histological findings are fissurating ulcers, acute and chronic inflammatory infiltrates and sometimes non-caseating granulomas. ${ }^{7}$ Thus, although the endoscopic presentation and unspecific histology

Table 1 Reported cases of Epstein-Barr virus oesophagitis among immunocompetent patients

\begin{tabular}{llll}
\hline Gender and age & Symptoms & Endoscopic findings & Diagnosis \\
Male, 23 years $^{4}$ & $\begin{array}{l}\text { Fever, diaphoresis, } \\
\text { lethargy, weight loss, } \\
\text { odynophagia, haematemesis, } \\
\text { lymphadenopathy }\end{array}$ & Multiple ulcerations & Positive Monospot test Symptomatic \\
Female, 27 years $^{5}$ & $\begin{array}{l}\text { Dysphagia, odynophagia } \\
\text { Male, } 48 \text { years }^{6}\end{array}$ & $\begin{array}{l}\text { Fever, nausea, dysphagia } \\
\text { ultiple, well-circumscribed }\end{array}$ & PCR analysis of biopsy Aciclovir \\
\hline
\end{tabular}


in this case could, in principle, have represented Crohn's disease, this was ruled out by the detection of EBV in the biopsy specimen and a positive serology combined with a normal bowel MRI.

Antiviral treatment of EBV oesophagitis was commenced in two out of three previous reported cases (table 1). However, any benefits from this treatment approach are highly unlikely given lack of effective antiviral therapy for $\mathrm{EBV}$, as detailed in the references. ${ }^{89}$ We successfully treated our patient symptomatically and this approach resulted in rapid symptom relief likely due to the condition in this particular patient being relatively mild and self-limiting. In cases of more severe or chronic active EBV infection, corticosteroids and ciclosporin may be commenced. ${ }^{10}$

In conclusion, primary $\mathrm{EBV}$ infection presenting as severe ulcerative oesophagitis in healthy immunocompetent individuals is extremely rare but should be remembered as a differential diagnosis especially if suspicion of infectious oesophagitis or Crohn's disease is raised combined with non-specific endoscopic findings of long and deep, circular or linear ulcerations. Suspicion would thus lead to earlier diagnosis with appropriate serological and histological investigations for EBV. Careful examinations to rule out concomitant causes for immunosuppression are also recommended. This diagnosis can be very challenging and should rely on collective evaluations of serology, as well as immunohistochemical stainings and PCR analysis of biopsies. The condition has a favourable prognosis and most cases can be treated symptomatically.

Contributors Study concept and design: CS. Acquisition of data: all authors. Analysis and interpretation of data: all authors. Drafting of the manuscript: RDL and CS. Critical revision of the manuscript for important intellectual content: all authors.

Funding The authors have not declared a specific grant for this research from any funding agency in the public, commercial or not-for-profit sectors.
Competing interests None declared.

Patient consent for publication Not required.

Provenance and peer review Not commissioned; externally peer reviewed.

Data availability statement Data sharing not applicable as no data sets generated and/or analysed for this study.

Open access This is an open access article distributed in accordance with the Creative Commons Attribution Non Commercial (CC BY-NC 4.0) license, which permits others to distribute, remix, adapt, build upon this work non-commercially, and license their derivative works on different terms, provided the original work is properly cited, appropriate credit is given, any changes made indicated, and the use is non-commercial. See: http://creativecommons.org/licenses/by-nc/4.0/.

ORCID iD

Casper Steenholdt http://orcid.org/0000-0003-3898-4212

\section{REFERENCES}

1 Cohen Jl. Epstein-Barr virus infection. N Engl J Med 2000;343:481-92.

2 Hoversten P, Kamboj AK, Katzka DA. Infections of the esophagus: an update on risk factors, diagnosis, and management. Dis Esophagus 2018;31. doi:10.1093/dote/doy094. [Epub ahead of print: $01 \mathrm{Dec}$ 2018].

3 Kitchen VS, Helbert M, Francis ND, et al. Epstein-Barr virus associated oesophageal ulcers in AIDS. Gut 1990;31:1223-5.

4 Tilbe KS, Lloyd DA. A case of viral esophagitis. J Clin Gastroenterol 1986;8:494-5.

5 Pape M, Mandraveli K, Sidiropoulos I, et al. Unusual Epstein-Barr esophageal infection in an immunocompetent patient: a case report. J Med Case Rep 2009;3:7314.

6 Annaházi A, Terhes G, Deák J, et al. Fulminant Epstein-Barr virus esophagitis in an immunocompetent patient. Endoscopy 2011;43 Suppl 2 UCTN:E348-9.

7 Pimentel AM, Rocha R, Santana GO. Crohn's disease of esophagus, stomach and duodenum. World J Gastrointest Pharmacol Ther 2019;10:35-49.

8 De Paor M, O'Brien K, Fahey T, et al. Antiviral agents for infectious mononucleosis (glandular fever). Cochrane Database Syst Rev 2016;12:Cd011487.

9 Ahuja NK, Clarke JO. Evaluation and management of infectious esophagitis in immunocompromised and immunocompetent individuals. Curr Treat Options Gastroenterol 2016;14:28-38.

10 Cohen Jl. Optimal treatment for chronic active Epstein-Barr virus disease. Pediatr Transplant 2009;13:393-6. 